\title{
Pension fund management and international investment - A global perspective
}

Received: 14th January, 2005

\section{E. Philip Davis}

is Professor of Economics and Finance at Brunel University, Visiting Fellow at the National Institute of Economic and Social Research, an associate member of the Financial Markets Group at LSE, Associate Fellow of the Royal Institute of International Affairs and Research Fellow of the Pensions Institute at Birkbeck College, London.

\begin{abstract}
This paper ${ }^{1}$ seeks to clarify the role of international investment in pension fund investment strategies. ${ }^{2}$ It draws on experience of Organisation for Economic Cooperation and Development (OECD) countries and of selected emerging market economies (EMEs) with established funded pension systems. It looks at aspects of international investment, empirically, at domestic and international asset returns of the returns and two policy issues - namely arguments for and against pension fund portfolio regulations limiting international investment and the implications for capital flows and asset prices of ageing in the coming decades.
\end{abstract}

Keywords: pension fund investment strategies; emerging market economies (EMEs); international investment; pension fund portfolio regulations

\section{Issues in international investment}

\section{Arguments favouring international investment}

Modern portfolio theory ${ }^{3}$ suggests that holding a diversified portfolio of assets in a domestic market can eliminate unsystematic risk resulting from the different performance of individual firms and industries, but not the systematic risk resulting from the performance of the

E. Philip Davis

Department of Economics and Finance, Brunel University, Room SS251, Uxbridge, Middlesex UB8 3PH, UK.

Tel: +44 (0)1895 203 172; Fax: +44 (0)1895 203 384; e-mail:

philip.davis@brunel.ac.uk economy as a whole. In an efficient and integrated world capital market, systematic risk would be minimised by holding the global portfolio, wherein assets are held in proportion to their distribution by current value between the national markets. ${ }^{4}$ In effect, the improvement in the risk-return position from diversification more than compensates for the additional element of volatility arising from currency movements.

Several ways may be envisaged whereby a strategy of international diversification should reduce risk. Crucially, to the extent that national trade cycles are not correlated and shocks to equity markets tend to be country-specific, the investment of part of the portfolio in other markets can reduce systematic risk for the same return. In the medium term, the profit share in national economies may move differentially, which implies that international investment hedges the risk of a decline in domestic profit share and hence in equity values. ${ }^{5}$ And in the very long term, imperfect correlation of 
demographic shifts should offer protection against the effects on the domestic economy of ageing of the population. ${ }^{6}$ In effect, international investment in countries with a relatively young population may be essential to prevent battles over resources between workers and pensioners in countries with an ageing population, which could occur even with funding as pensioners consume part of that country's gross domestic product (GDP). ${ }^{7}$

Supporting arguments may be derived from the special circumstances of individual countries or from inefficiencies in global capital markets. There may be industries offshore (oil, gold mining etc) which are not present in the domestic economy, investment in which will reduce unsystematic risk even if trade cycles were correlated. If oil prices change it is best to hold assets in both oil exporters (who benefit from an oil price rise and lose from a fall) and importers (vice versa). A high dependency on oil would imply a higher weighting towards oil producers.

The domestic stock market may itself be poorly diversified, being dominated by a small number of large companies (eg the Netherlands), or unduly exposed to one type of risk (eg Canada and raw materials). If the domestic currency tends to depreciate (as in the past in the UK), real returns on foreign assets will be boosted correspondingly, and vice versa for appreciation (although in the long run, real returns will be equalised if purchasing power parity holds). This implies an additional inflation hedge. Other economies (eg the US in recent years) may be more successful in terms of growth than the domestic economy and hence offer higher total returns, given stock market returns ultimately depend on dividends, which in turn are a function of profits and GDP growth. Similarly, there may be a higher marginal productivity of capital in lower-wage countries (eg Korea) which may be attractive to investors. ${ }^{8}$ For investors in certain markets, international investment may be stimulated by the unavailability of certain instruments in the home market such as index-linked bonds. Equally, international investment avoids the risk of catastrophic failure of domestic financial markets due to war, revolution or other disasters, as has happened to Germany and Japan in 1945 and Russia in 1917. In the special case of Japanese pension funds, investment in foreign assets provides a hedge against the possibility of a catastrophic domestic earthquake.

Finance-theory arguments for international investment ${ }^{9}$ apply strongly to emerging markets. In many developing countries the financial markets may themselves be poorly developed, offering only bank deposits. Even where they are active, securities markets may be highly vulnerable to policy related or external macroeconomic shocks, leading to high and variable inflation that are damaging to the value of domestic financial assets. If the domestic currency tends to depreciate owing to inflation, real returns on foreign assets will be boosted, at least temporarily. Even more than for smaller OECD countries, the domestic stock market may itself be poorly diversified, being dominated by a small number of companies, or unduly exposed to one type of risk. There will be many industries offshore which are not present in the domestic economy, investment in which will reduce risk. Small markets particularly in developing countries may be inherently volatile and illiquid both due to their inherent characteristics and the entry and exit of foreign institutional investors. ${ }^{2}$ If there are higher mean returns in emerging markets than in OECD countries then there would be a trade-off of return and risk in investing 
Table 1: Correlations of monthly per cent changes in $\mathrm{MSCl}$ country stock indices

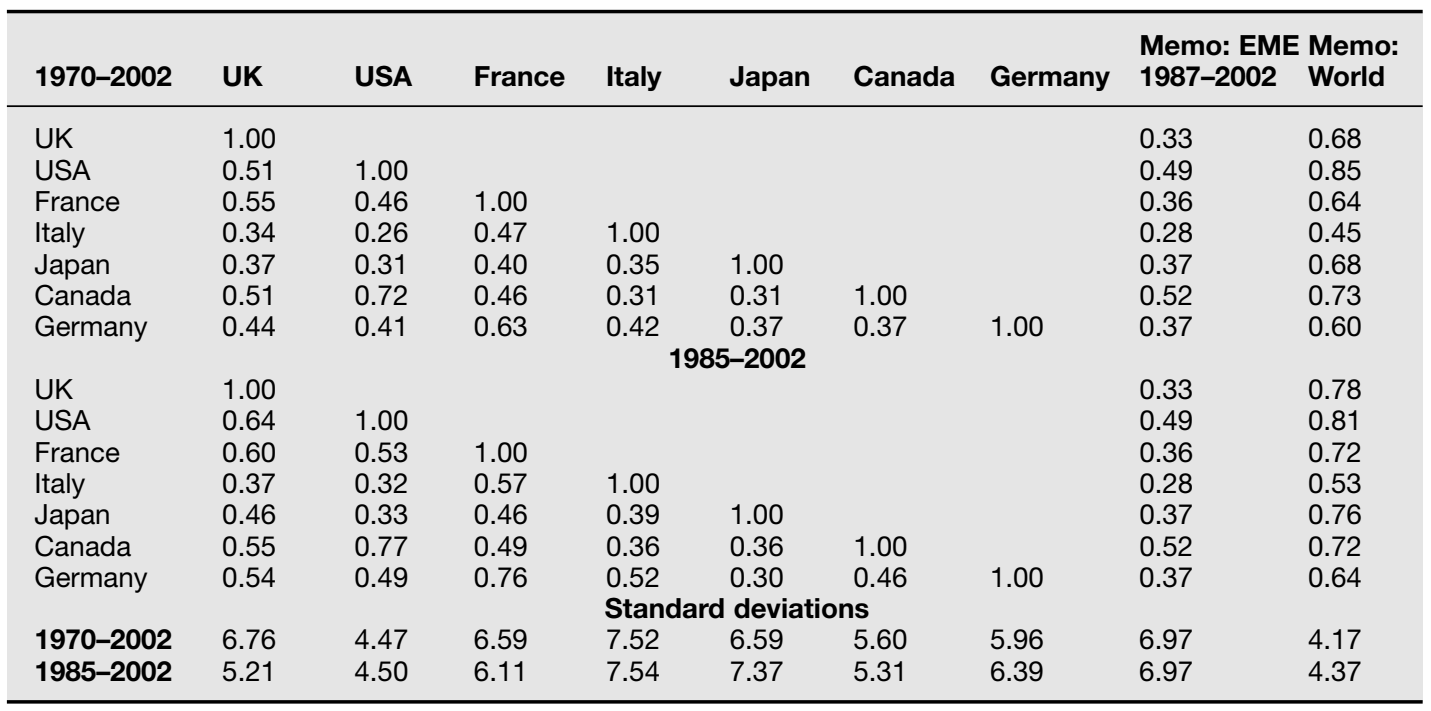

Source: MSCl.com website, own calculations. Note: EME data are only available from 1987-2001. World/EME correlation is 0.54 .

abroad. ${ }^{10}$ Experience suggests that this phenomenon is partly endogenous to pension reform but is not to be depended on in the long term.

In the context of these arguments, a number of academic studies using data over the long term have shown that investors free to choose foreign assets may obtain a better risk/return trade-off than if they are restricted to assets of one country. ${ }^{11}$ In this context, we illustrate three important results in Tables 1-3.

Table 1 shows the correlations between equity index returns for the G-7 using monthly changes in the MSCI indices. The correlations for the G-7 from 1970 to 2002 are 0.43 on average, as compared with correlations of 0.9 for stocks in a domestic market. This indicates scope for risk reduction via international investment. The data for 1985 to 2002 indicate that the correlations have risen over time to an average of 0.49 , showing the integration of global stock markets and growing scope of international investment, but remain relatively low. Correlations of the EME index with the OECD countries are lower than those between OECD countries, showing benefits of diversification in both directions. Note also that the volatility of the world index is the lowest of any in the table, showing the diversification benefits it offers.

Table 2 shows the results for the G-7 of a factor regression on the determinants of share prices of individual companies. ${ }^{12}$ The numbers indicate the percentage of volatility of an individual company stock (averaged for a number of stocks in each country) accounted for by each factor. The domestic factor is the dominant influence, with addition of the other factors adding very little to the outcome. The result is consistent with diversification benefits shown in Table 1 . Note, however, that the results date back to the 1980 s, so the relative importance of factors may have changed. In addition, developments such as EMU will have led to drastic changes in the effects for the countries concerned (with a euro-wide factor and industry factors becoming dominant for EMU member countries).

Table 3 provides evidence ${ }^{13}$ for longer term returns and risks to international 
Table 2: Relative importance of factors in explaining return on a stock

\begin{tabular}{|c|c|c|c|c|c|}
\hline \multirow[b]{2}{*}{ Country } & \multicolumn{4}{|c|}{ Average R-squared of regression on factors } & \multirow[b]{2}{*}{$\begin{array}{l}\text { Joint test of } \\
\text { all factors }\end{array}$} \\
\hline & $\begin{array}{l}\text { Single } \\
\text { World }\end{array}$ & $\begin{array}{l}\text { ts } \\
\text { Industrial }\end{array}$ & Currency & Domestic & \\
\hline UK & 0.20 & 0.17 & 0.01 & 0.53 & 0.55 \\
\hline USA & 0.26 & 0.47 & 0.01 & 0.35 & 0.55 \\
\hline France & 0.13 & 0.08 & 0.01 & 0.45 & 0.60 \\
\hline Italy & 0.05 & 0.03 & 0.00 & 0.35 & 0.35 \\
\hline Japan & 0.09 & 0.16 & 0.01 & 0.26 & 0.33 \\
\hline Canada & 0.27 & 0.24 & 0.07 & 0.45 & 0.48 \\
\hline Germany & 0.08 & 0.10 & 0.00 & 0.41 & 0.42 \\
\hline G-7 average & 0.15 & 0.18 & 0.02 & 0.40 & 0.47 \\
\hline
\end{tabular}

Source: Solnik and De Freitas cited in Bodie et al. ${ }^{12}$

Table 3: Returns on global stock indices, 1921-96

\begin{tabular}{llll}
\hline Index & Real return (arithmetic) & Standard deviation & Real return (geometric) \\
\hline USA & 5.5 & 15.8 & 4.3 \\
Non-USA & 3.8 & 10.0 & 3.4 \\
Global & 5.0 & 12.1 & 4.3 \\
Survived markets & 4.6 & 11.1 & 4.0 \\
\hline
\end{tabular}

Source: Jorion and Goetzmann. ${ }^{13}$

equity investment over the period 1921 to 1996 , using GDP to weight portfolio holdings. The results show that there is a major reduction in risk; even the inclusion of markets that failed (ie ceased to function entirely) does not greatly reduce the global total return.

\section{Benefits to pension funds}

For all pension funds, a key aim of investment is to match, or preferably exceed, the growth of average labour earnings, given that this determines the replacement rate at retirement, the key determinant of the liabilities of the fund. The traditional approach to investment is the mean-variance approach based on risk and return, first developed by Tobin and Markowitz. Optimal investment involves the choice of a trade off between low risk and high return (chosen from the frontier of efficient portfolios), as appropriate for the investor's preferences. This is relevant for defined contribution (DC) pension funds. The case is more complex for defined benefit (DB) funds, where there is a guarantee of returns by the sponsor. Here optimal investment may entail Asset Liability Management (ALM) wherein the long-term balance between assets and liabilities is maintained by choice of a portfolio of assets with similar return, risk and duration characteristics to liabilities. There may also be shortfall risk considerations, where minimum-funding regulations lead investors to maximise the return on the portfolio subject to a ceiling on the probability of incurring a loss. Some funds may seek to avoid such risk via immunisation or matching of assets and liabilities, but this may be difficult or costly for funds whose liabilities rise with wage inflation.

In this context, a significant number of benefits for pension funds arise from international investment. The most important is the broadening of the frontier of efficient portfolios as a consequence of international investment possibilities. This means that for a meanvariance based investor such as a DC pension fund, a higher return is available 
for the same level of risk (when risk preferences dictate high returns for immature funds) or lower risk for the same returns (when risk considerations dictate low risk for mature funds). Given risk aversion falls with income and wealth, low income pensioners as in emerging market economies will be particularly averse to avoidable risks to retirement income.

In terms of DB funds, similar considerations will for the most part be important. In an ALM approach, it can be argued that international assets will tend to be part of a portfolio of assets with similar return, risk and duration characteristics to pension liabilities, as long as the fund is not winding down (ie with very short duration liabilities). Indeed, foreign assets may offer enhanced inflation protection, as the exchange rate depreciates during periods of inflation when domestic asset returns are poor.

Where shortfall risk considerations are important for DB funds, it is an empirical question whether international assets offer greater downside risk than domestic ones, but better diversification and the exchange rate offset for inflation suggests this would not be the case. Well developed derivatives markets would allow protection. In this context, we note that estimation ${ }^{14}$ of the frontier of efficient portfolios based on historical variances and covariances of asset returns shows minimum risk for a given return to be at an exposure to foreign assets of 20-30 per cent. Such calculations only show average risks rather than extreme values, however. Shortfall risk can arise from domestic as well as international investment, and such risk in the domestic economy may itself be relatively high in emerging market economies subject to high and volatile inflation.

Foreign assets may be avoided where the investment policy is merely to immunise or match assets and liabilities.
In these cases a more precise match is provided by domestic assets. To the extent that pensioners will seek to spend part of their income on foreign goods and services, the case for a degree of international investment may remain, to an extent, dependent on the import share in the consumption basket.

International investment benefits pension funds at a wider level. In small countries, such as the Netherlands and Singapore, the assets of pension funds and other institutional investors may exceed the entire domestic equity market, and hence simple liquidity considerations necessitate international investment, abstracting from risk/return considerations, if regulations permit. Moreover, in emerging market economies, pension funds may be vulnerable to banking crises as well as the more general risks noted above, given that funded pension systems in their early stages hold a certain amount of bank assets. ${ }^{15}$ International investment avoids this and related 'catastrophic risks'. ${ }^{9}$

\section{Reasons for 'home asset preference' of pension funds}

Given the force of these arguments, it is a puzzle that pension funds tend to invest at least 60 per cent of their assets in the home market, and in most, the figure is over 90 per cent, see Table 4. Enormous differences in expected yields would be needed to account for such portfolios in the context of the theory of efficient markets. ${ }^{16}$ Reasons for this home asset preference include the following.

\section{Liabilities may play a role}

The arguments above for sizeable exposure to international assets apply best to a portfolio that is following a mean-variance approach such as a DC pension fund, or an ongoing DB pension 
Table 4: Pension funds' portfolio composition 1998

\begin{tabular}{|c|c|c|c|c|c|c|c|c|}
\hline $\begin{array}{l}\text { Percent of } \\
\text { total }\end{array}$ & Liquidity & Loans & $\begin{array}{l}\text { Domestic } \\
\text { bonds }\end{array}$ & $\begin{array}{l}\text { Domestic } \\
\text { equities }\end{array}$ & Property & $\begin{array}{l}\text { Foreign } \\
\text { assets }\end{array}$ & $\begin{array}{l}\text { Memo: } \\
\text { pension } \\
\text { provision }\end{array}$ & $\begin{array}{l}\text { Memo: } \\
\text { assets/ } \\
\text { GDP }\end{array}$ \\
\hline Australia & 14 & 4 & 12 & 43 & 6 & 18 & DC & 42 \\
\hline Canada & 5 & 3 & 38 & 27 & 3 & 15 & $\mathrm{DB} / \mathrm{DC}$ & 47 \\
\hline Denmark & 1 & 0 & 59 & 23 & 6 & 11 & $\mathrm{DC}$ & 22 \\
\hline Germany & 0 & 33 & 43 & 10 & 7 & 7 & $\mathrm{DB}$ & 15 \\
\hline Japan & 5 & 14 & 34 & 23 & 0 & 18 & DB & 17 \\
\hline France & 0 & 18 & 65 & 10 & 2 & 5 & DB & 7 \\
\hline Italy & 0 & 1 & 35 & 16 & 48 & 0 & DC & 2 \\
\hline Netherlands & 2 & 10 & 21 & 20 & 7 & 42 & DB & 116 \\
\hline Sweden & 0 & 0 & 64 & 20 & 8 & 8 & $\mathrm{DB} / \mathrm{DC}$ & 49 \\
\hline Finland & 13 & 0 & 69 & 9 & 7 & 2 & DB & 8 \\
\hline Switzerland & 11 & 0 & 29 & 17 & 26 & 17 & $\mathrm{DC}$ & 111 \\
\hline UK & 4 & 0 & 14 & 52 & 3 & 18 & $\mathrm{DB} / \mathrm{DC}$ & 87 \\
\hline USA & 4 & 1 & 21 & 53 & 0 & 11 & $\mathrm{DB} / \mathrm{DC}$ & 72 \\
\hline Chile & 15 & 17 & 44 & 21 & 3 & 4 & DC & 45 \\
\hline Singapore & 28 & 0 & 70 & 0 & 0 & 0 & DC & 60 \\
\hline Malaysia & 24 & 27 & 32 & 18 & 1 & 0 & DC & 51 \\
\hline
\end{tabular}

Sources: National flow of funds balance sheets, Mercer, W. (1999) 'European pension fund managers guide 1999', William M. Mercer, London. Chile: Palacios, R. and Pallares-Mirelles, M. (2000) 'International patterns of pension provision', World Bank, Washington DC.; Singapore and Malaysia: Asher, M. (2000) 'Social security reform imperatives; the South-East Asian case', Working Paper, National University of Singapore.

fund with inflation-linked liabilities following ALM considerations. For both types of fund, maturity will make the fund less willing to accept the risk of foreign assets. Funds following shortfall risk or immunisation strategies, or funds with very short term liabilities (eg due to winding up), may wish to avoid foreign assets altogether.

A related point is that foreign investment will not overcome systemic risks to world capital markets. Downside market movements, notably in equity markets, occur much more in parallel than do upside ones (as in the 1987 crash). ${ }^{17}$ Pension funds that are adverse to shortfall risk (eg owing to minimum funding requirements or low risk tolerance of asset managers) will therefore be cautious in assuming diversification benefits. Nevertheless, if such shocks are truly systemic, they are not avoided by domestic investment either.

\section{Efficiency of global markets}

The argument for the global portfolio assumes efficiency of markets. If markets are inefficient, for example showing bubbles, then global indexation by market capitalisation will not be an efficient strategy, as those who built up holdings of Japanese stocks in the late 1980s and early 1990s discovered. Or atypically high returns on domestic bonds, as historically in Germany, may encourage domestic investment.

Consistent with the point made above about the consumption basket, ${ }^{18}$ there remains an optimal level of international diversification in the presence of inefficient global markets. This is based on the 'openness' of the economy, and thus its exposure to output and inflation shocks. This suggests a higher level of international investment than is appropriate for small open economies (both OECD and emerging markets) with high import/GDP ratios, than in relatively closed economies such as the USA, Japan and the Euro area.

\section{Scepticism of purchasing power}

A related point is that there is scepticism regarding purchasing power parity 
Table 5: UK Pension Funds: Performance relative to benchmarks

\begin{tabular}{|c|c|c|c|c|c|c|}
\hline Percentage points & Average & $\begin{array}{l}1998 \\
\text { Standard } \\
\text { deviation }\end{array}$ & $\begin{array}{r}198 \\
\text { Average }\end{array}$ & $\begin{array}{l}989 \\
\text { Standard } \\
\text { deviation }\end{array}$ & $\begin{array}{r}199 \\
\text { Average }\end{array}$ & $\begin{array}{l}998 \\
\text { Standard } \\
\text { deviation }\end{array}$ \\
\hline USA & -2.3 & 2.1 & -3.7 & 2.0 & -0.9 & 1.0 \\
\hline Japan & 0.3 & 7.5 & -2.0 & 9.9 & 2.5 & 3.2 \\
\hline Continental Europe & -1.0 & 3.1 & -1.8 & 4.0 & -0.2 & 1.6 \\
\hline World & -1.6 & 6.0 & -3.1 & 5.1 & -0.2 & 6.7 \\
\hline UK & -0.4 & 0.7 & -0.4 & 0.9 & -0.3 & 0.6 \\
\hline
\end{tabular}

Note: Before 1987, local indices for the USA and Japan, MSCI for Europe.

After 1987, FT-A indices.

Source: WM (1999) 'WM UK pension fund annual review, 1998', The WM Company.

holding, even in the very long term. ${ }^{10}$

This can be justified by the existence of long-term shifts in real exchange rates, which means currency mismatching can involve risk, especially for a mature fund. The issue will be of greater importance, the higher the share of non-traded goods that pensioners buy. Whereas short-term currency fluctuations can be hedged against, the optimal degree of hedging is highly uncertain. ${ }^{17}$

\section{Equities, property an bonds}

The arguments about global diversification may be considered to apply to different degrees in the cases of equities, property and bonds. They apply most precisely to equities, although one counter-argument is that diversification may be obtained by investment in the domestic market if domestic companies carry out foreign direct investment. Bond markets are more globally integrated, and hence there is less benefit from diversification out of domestic markets. Property is a real asset similar to equity, but is less liquid and more reliant on imperfect local information. This makes international diversification more difficult, although ${ }^{19}$ returns are for that reason less internationally correlated, and hence, property company shares offer considerable diversification benefits.

\section{Information}

There are also issues of information and other costs. Better information on home markets may be a reason why investors choose to concentrate their investments there. Consistent with this, Table 5 shows that UK pension funds obtain much lower returns in foreign markets, relative to passive benchmarks, than they do in their home market (which begs the question why do they not index abroad?) Foreign investors in Japan concentrate on larger stocks, which are better known. ${ }^{20}$ Prices of Mexican stocks declined more than closed-end funds traded in the USA, suggesting that investors in Mexico were better informed about fundamentals than those in the USA. ${ }^{21}$ There will be sunk costs of setting up access to market information, that institutions may choose not to incur, as they cannot be recovered when emerging from the market. Equally, higher transactions costs, linked also to clearance, settlement, and custody, may limit investment in foreign markets. UK pension funds also earned negative returns from international market timing (ie switching between markets). ${ }^{22}$

\section{Global corporate ownership}

Home bias may to some extent be driven by the structure of corporate ownership around the world. Global market portfolios based on outstanding 
shares may give a false impression of the proportion of shares that are actually tradeable, given that a significant proportion may be firmly held in large stakes which control the corporation in question. This is particularly important outside the USA and the UK. This implies that an equilibrium degree of home bias may be appropriate for US and UK investors (because foreign markets have low free float) and elsewhere (because controlling shareholders are usually domestic). ${ }^{23}$

A weaker justification for home asset preference is that international investment poses additional risk compared with domestic investment - settlement, liquidity, transfer, and exchange rate risk. But settlement, liquidity, and transfer risks may be avoided by appropriate choice of markets. Exchange rate risk can be hedged, ${ }^{12}$ and, viewed in the context of modern portfolio theory rather than in isolation, contributes to, rather than offsetting, the benefits of offshore investment in terms of returns and diversification of risk, notably for equities. In practice, foreign bonds are often hedged while foreign equities are not.

\section{Foreign asset restrictions}

Finally, home asset preference is widely considered to be driven by foreign asset restrictions in portfolio regulations. Given the importance of this issue the pros and cons of limiting international investment are discussed separately below. Suffice to say here that the main choice facing the authorities is between so called prudent person rules typically allowing international investment and quantitative portfolio restrictions which usually limit it, although authorities may also vary the tightness of such portfolio restrictions. To offer brief definitions, a quantitative portfolio regulation is simply a quantitative limit on holdings of a given asset class. Typically, those instruments whose holdings are limited are those with high price volatility and/or low liquidity, such as equities, real estate and foreign assets. Explicit allowance is by definition not made for potentially offsetting correlations between types of financial instrument. Such regulations thereby override free choice of investments. Meanwhile, a prudent person rule stipulates that investments should be made in such a way that they are considered to be handled prudently (as someone would do in the conduct of his or her own affairs). The process of making the investment is the key test of prudence. The aim is to ensure adequate diversification, thus protecting the beneficiaries against insolvency of the sponsor and investment risks. ${ }^{24}$ The prudent person rule, in effect, allows the free market to operate throughout the investment process.

For DB funds, solvency and minimum funding rules and their interaction with associated accounting arrangements may also play a crucial role in influencing portfolios, and may limit international investment independently of portfolio restrictions. This is because they determine the size and volatility of the surplus, as well as defining the rules for dealing with a corresponding deficit. They influence the likelihood and $\operatorname{cost}^{25}$ of any deficiency, and hence the importance for pension funds of maintaining a stable valuation of assets relative to liabilities, independent of portfolio limits. Minimum rates of return set annually by regulation can constrain diversification even when quantitative limits are not stringent (OECD 2000). They limit holdings of volatile assets which could reduce returns below the limit in one year, even if they offer a high mean return. And application of accounting principles which insist on 
positive net worth of the fund at all times, carry equities on the balance sheet at the lower of book value and market value $^{26}$ and calculate returns net of unrealised capital gains (as in Germany until recently, and Switzerland) may also restrain international asset holdings independently of portfolio regulations.

\section{International investment of pension funds in practice}

This section, seeks to assess how the issues brought out above arise in practice using data over 25 years for the pension fund sectors of ten OECD countries (Australia, Canada, Denmark, Germany, Japan, the Netherlands, Sweden, Switzerland, the UK and the USA) and three emerging market economies with long experience of pension funds and pension fund investment (Chile, Singapore and Malaysia). These funded pension systems are mandatory in the cases of Australia, Denmark, Sweden, Switzerland and the three emerging market economies, and voluntary elsewhere. These mandatory systems are all DC, while systems elsewhere are either a mixture or purely $\mathrm{DB}$. In most of the countries, pension funds are sizeable, with assets amounting to 50 per cent or more of GDP. Investment is by private managers except in Singapore, Malaysia and, until recently, Sweden. ${ }^{27}$

\section{Asset return characteristics}

Complementing the data already presented, Table 6 illustrates the risk and return characteristics of international assets from 1970-1995, compared to domestic assets that are held by pension funds, to evaluate their potential role in pension fund investment. Note that these are real returns and their corresponding risks. They are also total returns, with estimated capital gains and losses on bonds, equities and real estate being added to the yield. Foreign asset returns are calculated by use of a simple weighting scheme of nominal total returns to G-7 country equities and bonds, based on rough estimates of world capitalisation weights. ${ }^{28}$ These weighted returns are then derived in domestic currency in real terms by subtracting the change in the nominal effective exchange rate and the domestic inflation rate.

The line OECD average provides a summary for industrial countries. It is shown that the highest real returns are typically from (domestic) equities, which also have the greatest volatility. Other high-return assets are property and foreign equities, followed by bonds and loans, and, finally, short-term assets. As regards standard deviations, Table 6 verifies the proposition that the risks on foreign assets are generally lower than for domestic assets of the same type because of the diversification benefits of foreign assets, which more than offset exchange rate risk.

Meanwhile, contrary to the expectations of finance theory, the volatility pattern is not entirely congruent with the pattern of real yields, with total returns on bonds showing a relatively high volatility despite rather low real returns. This is partly linked to the fact that in the 1970s, the real value of bonds fell sharply with high and volatile inflation, a pattern that was unique in history and has been much less characteristic of the 1980s and 1990s.

Table 5 also shows inflation and growth in real average earnings. The latter, a key target of pension fund investment, has been an average of 2 per cent for the countries shown. Inflation averaged 6 per cent over the period shown, although levels for individual 
Table 6: Annual real asset returns and risks over 1967-1995

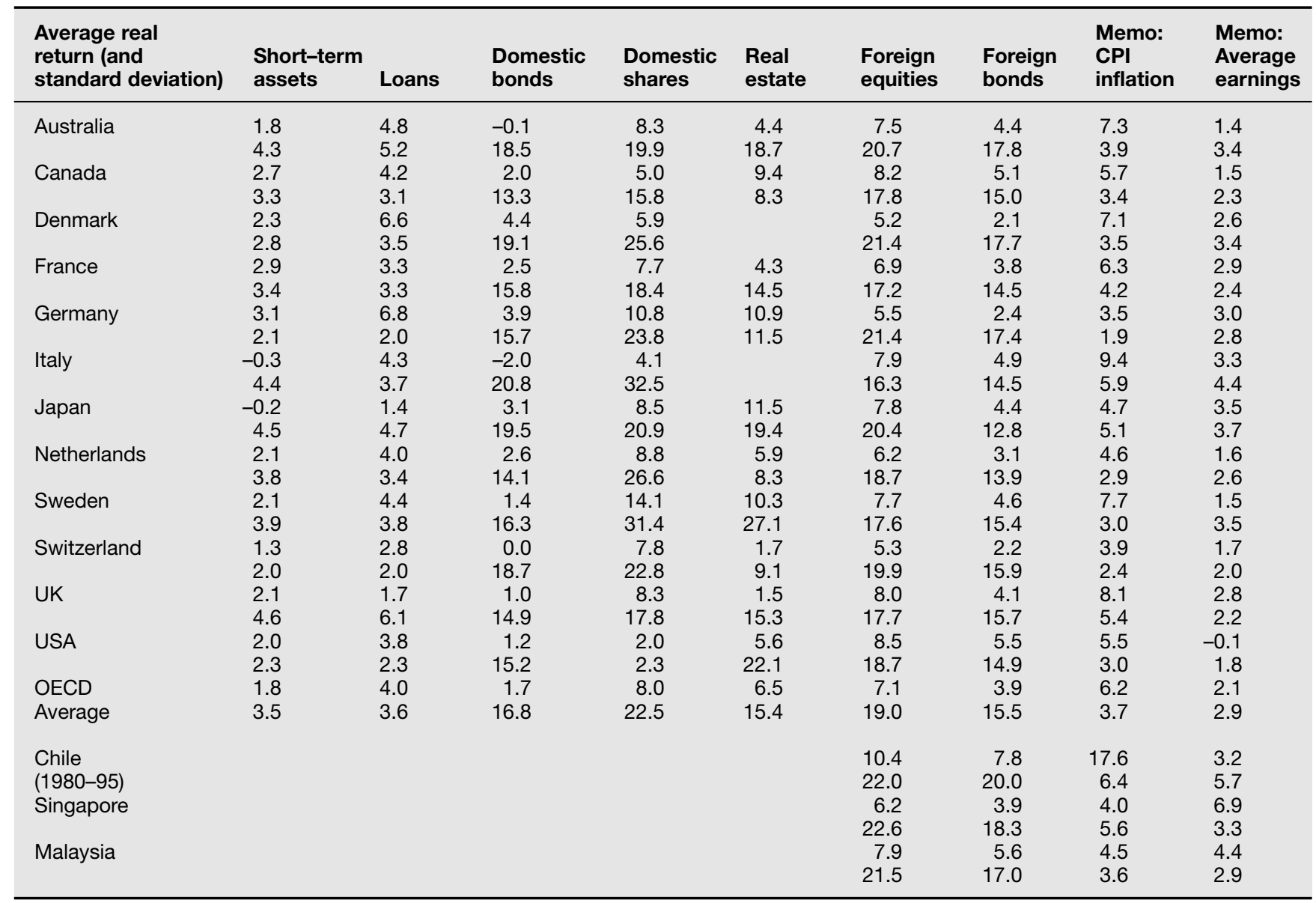

Source: OECD, BIS.

countries varied significantly. The limited data we have for the three emerging market economies shows that average earnings growth considerably exceeds that in OECD countries, in line with economic development, while Chile experienced higher inflation over 1980-1995. ${ }^{29}$ Returns on foreign assets are comparable with those in OECD countries.

\section{Portfolios of pension funds}

Patterns of portfolio shares in 1998 were shown in Table 4. There are major contrasts in terms of the proportion of foreign assets, as well as the balance for domestic assets between bonds and equities. The largest share of foreign assets is in the Netherlands (42 per cent), a small open economy with very large pension funds relative to the size of the domestic financial markets. Note, however, that although many of these characteristics are shared by the Scandinavian countries, the holding of foreign assets is much lower (owing to portfolio restrictions on foreign investment). Shares of foreign assets are close to 20 per cent in Australia, Canada, Japan, Switzerland and the UK, of which Japan and the UK are medium-to large economies while the others are again relatively small. The USA, a large open 
Table 7: Foreign assets regulations for pension funds

\begin{tabular}{|c|c|c|}
\hline Country & $\begin{array}{l}\text { General approach to } \\
\text { investment regulation }\end{array}$ & Foreign asset restrictions \\
\hline Australia & Prudent person rules (PPR) & $\begin{array}{l}\text { No currency matching limit but tax on income from } \\
\text { foreign assets }\end{array}$ \\
\hline Canada & PPR & $\begin{array}{l}\text { No currency matching limit but foreign securities } \\
\text { maximum of } 30 \% \text { of fund }\end{array}$ \\
\hline Denmark & $\begin{array}{l}\text { Quantitative asset } \\
\text { restrictions (QAR) }\end{array}$ & $80 \%$ currency matching limit \\
\hline Finland & PPR/QAR & $\begin{array}{l}80 \% \text { currency matching limit, } 5 \% \text { in non-EEA countries, } \\
20 \% \text { in currencies other than the euros }\end{array}$ \\
\hline Germany & QAR & $\begin{array}{l}80 \% \text { currency matching limit; } 35 \% \text { limit on EU equity, } \\
10 \% \text { on non-EU equity, } 10 \% \text { non-EU bonds }\end{array}$ \\
\hline Italy & PPR/QAR & $\begin{array}{l}67 \% \text { currency matching limit. Non-OECD securities limit } \\
\text { to } 5 \%\end{array}$ \\
\hline Japan & PPR & None (Since 1998 only) \\
\hline Netherlands & PPR & None \\
\hline Sweden & QAR & $\begin{array}{l}\text { Currency matching required. Foreign assets limited to } \\
5-10 \% \text { of the fund }\end{array}$ \\
\hline Switzerland & QAR & $30 \%$ limit on foreign assets \\
\hline United Kingdom & PPR & None \\
\hline United States & PPR & None \\
\hline Chile & QAR & $80 \%$ currency matching limit \\
\hline Singapore & [PPR $]$ & $\begin{array}{l}\text { Government invests assets at its discretion but holders } \\
\text { are 'credited' with returns equivalent to bank deposits }\end{array}$ \\
\hline Malaysia & QAR & $70 \%$ of assets in domestic government bonds \\
\hline
\end{tabular}

Note: PPR: prudent person rules, QAR: quantitative asset restrictions.

Source: OECD (2004) 'Survey of investment regulations of pension funds', Financial Affairs Department, Organisation for Economic Co-operation and Development, Paris.

economy, has 11 per cent in foreign assets. Finally, there are a number of countries with very few foreign assets, including Denmark, Germany, France, Italy, Sweden and Finland. ${ }^{30}$ There appears to be no strong link from DB or DC to foreign investment, although there is a slight tendency for more international assets to be held in largely DB-based systems.

In the emerging market economies, the stated level of foreign assets is very low, despite the fact that they are small open economies where pension funds are very large relative to the economy and domestic financial markets. Note, however, that in Singapore, the fund is administered by the government investment agency, the Central Provident Fund (CPF), although the actual investment of the accumulated monies is carried out by the Government of Singapore Investment Corporation
(GSIC) and the Monetary Authority of Singapore (MAS). The investment of the $\mathrm{CPF}$ is in non-tradable government bonds and liquid bank deposits with the MAS. The MAS then invests the assets as foreign exchange reserves, and the GSIC in foreign equities. Moreover, in Chile, bonds all tend to be indexed and thus offer inflation protection. Foreign investment in Chile rose sharply to 10 per cent in 2000 following deregulation, to allow hedging of currency risk using derivatives.

\section{Portfolio regulations on pension funds}

As background for interpreting the portfolio data, Table 7 illustrates the pattern of portfolio regulations in the OECD countries as well as in Chile, Singapore and Malaysia. Note that this information is subject to change as regulations are amended and its accuracy 
Table 8: Headroom relative to portfolio restrictions on foreign assets

\begin{tabular}{ll}
\hline & Per cent of portfolio \\
\hline Canada & 15 \\
Germany & 13 \\
Finland & 18 \\
Italy & 33 \\
Sweden & 2 \\
Switzerland & 13 \\
Chile & 16 \\
Malaysia & 30 \\
\hline
\end{tabular}

Source for OECD countries: See Table 4.

cannot be guaranteed. In Japan, the Netherlands, UK and the USA, pension funds are subject to a 'prudent person rule'. This is a relatively recent phenomenon in Japan, where regulations limited international investment until 1998. Australian funds are not subject to prudent person rules but taxation provisions, which enable domestic dividend tax credits to be offset against other tax liabilities, and are reportedly a major disincentive to international investment. ${ }^{31}$ Canadian funds, despite having a prudent person rule, face limits on the share of external assets (but not their composition) as tax regulations limit foreign investment to 30 per cent of the portfolio. A tax of 1 per cent of excess foreign holdings was imposed for every month the limit is exceeded.

The other countries have quantitative restrictions on foreign investment. This helps to explain the low levels of foreign investment there. For example, German funds are subject to the 20 per cent limits on foreign investment imposed on life insurers under the relevant EU Directives, despite the different liability composition of pension funds to life insurance. In Finland, this EU limit is supplemented by tighter limits on investment outside the European economic area. Swedish funds are limited to five to ten per cent foreign investment, and Swiss and Italian funds to 30 per cent and 33 per cent respectively.

In the emerging market economies, the limit in Chile is 20 per cent foreign assets, while in Malaysia, 70 per cent of assets must be in domestic government bonds. As noted, Singapore is a hybrid in that investments are carried out by the government independently of the fund and its returns (the government 'saves' the excess return over that on bank deposits as a contingency reserve for the 'future of the country').

Table 8 shows that there is considerable headroom relative to the foreign asset restrictions imposed by countries on their pension funds. The main exception is Sweden. Note that the interpretation of headroom could be on the one hand that there is no effect of the restrictions on normal business - or on the other that the existence of such restrictions may lead to very cautious portfolio management to avoid ever breaching them even if markets soar. The distinction is hard to test; as noted above, some home bias seems to occur even in the absence of regulation, due inter alia to accounting and solvency limits.

\section{Potential and actual returns on international investment}

This section seeks to address the degree to which pension funds' actual returns or potential domestic returns could be improved by more international investment. It uses a dataset for pension fund portfolios and asset returns covering the period 1970-1995. This is a sufficiently long and turbulent period to offer some reasonably robust conclusions. First, the calculations provide, an estimate of actual real returns on pension funds, calculated by weighting each portfolio share in each year by its expected return (as illustrated for a 
Table 9: Mean variance 1: Estimated real returns and risks on pension funds' portfolios and on foreign assets (1970-95)

\begin{tabular}{|c|c|c|c|c|c|}
\hline & $\begin{array}{l}\text { Actual } \\
\text { portfolios }\end{array}$ & $\begin{array}{l}50-50 \text { domestic } \\
\text { bonds and } \\
\text { equities }\end{array}$ & $20 \%$ foreign & $40 \%$ foreign & Global portfolio \\
\hline \multirow[t]{2}{*}{ Australia } & 1.8 & 3.5 & 4.0 & 4.6 & 6.1 \\
\hline & 11.4 & 17.5 & 16.5 & 16.1 & 18.2 \\
\hline \multirow[t]{2}{*}{ Canada } & 4.8 & 4.0 & 4.6 & 5.3 & 7.1 \\
\hline & 10.0 & 12.1 & 11.7 & 11.8 & 14.7 \\
\hline \multirow[t]{2}{*}{ Denmark } & 4.9 & 6.1 & 5.6 & 5.1 & 3.7 \\
\hline & 11.0 & 19.0 & 17.6 & 16.7 & 18.5 \\
\hline \multirow[t]{2}{*}{ Germany } & 6.0 & 6.4 & 5.9 & 5.4 & 3.9 \\
\hline & 5.9 & 17.7 & 16.1 & 15.3 & 18.4 \\
\hline \multirow[t]{2}{*}{ Japan } & 4.4 & 6.1 & 6.2 & 6.4 & 6.9 \\
\hline & 10.2 & 16.9 & 15.5 & 14.6 & 16.0 \\
\hline \multirow[t]{2}{*}{ Netherlands } & 4.6 & 5.5 & 5.4 & 5.2 & 4.8 \\
\hline & 6.0 & 18.3 & 17.2 & 16.2 & 14.7 \\
\hline \multirow[t]{2}{*}{ Sweden } & 2.1 & 8.0 & 7.6 & 7.3 & 6.3 \\
\hline & 13.2 & 20.1 & 17.7 & 15.8 & 14.8 \\
\hline \multirow[t]{2}{*}{ Switzerland } & 1.8 & 2.4 & 2.6 & 2.9 & 3.7 \\
\hline & 7.7 & 18.1 & 16.9 & 16.2 & 17.0 \\
\hline \multirow[t]{2}{*}{ UK } & 5.9 & 4.7 & 4.9 & 5.2 & 5.9 \\
\hline & 12.8 & 15.4 & 14.8 & 14.4 & 15.0 \\
\hline \multirow[t]{2}{*}{ USA } & 4.5 & 4.4 & 5.0 & 5.6 & 7.5 \\
\hline & 11.8 & 13.3 & 12.8 & 12.8 & 15.2 \\
\hline OECD & 4.4 & 6.3 & 6.3 & 6.3 & 6.6 \\
\hline Average & 9.6 & 15.7 & 14.7 & 14.1 & 15.3 \\
\hline Chile & 13.0 & & & & 9.1 \\
\hline (1980-95) & 9.5 & & & & 19.1 \\
\hline \multirow[t]{2}{*}{ Singapore } & 1.3 & & & & 5.1 \\
\hline & 5.4 & & & & 18.4 \\
\hline \multirow[t]{2}{*}{ Malaysia } & 3.0 & & & & 6.7 \\
\hline & 3.9 & & & & 17.2 \\
\hline
\end{tabular}

Source: Davis and Steil ${ }^{30}$, own calculations.

slightly longer period in Table 4) and subtracting the inflation rate. Secondly, a benchmark is provided based on the returns on a dummy portfolio of 50 per cent domestic bonds and 50 per cent domestic equities (referred to as $50-50$ domestic). Compared to the actual returns, this illustrates the influence of regulations limiting domestic investment in equities as well as risk preferences. Successive estimates of the effects of diversifying this portfolio (while retaining the balance between equities and bonds), up to 20 per cent international and then 40 per cent international, and finally a full global portfolio are provided. Note that in the last case, there will only be domestic assets for the G-7 countries according to their global capitalisation weights and no domestic assets for the smaller countries. Unfortunately, consistent data for domestic security returns back to 1970 were not available for the EMEs, so the focus is on the comparison of the actual portfolio with the global portfolio.

Following the discussion above, the results are divided into those relevant to the traditional mean-variance approach, to shortfall risk and to ALM. Beginning with mean-variance, Table 9 shows that for the ten OECD countries, actual portfolios had a lower return than a 50-50 domestic portfolio, and also markedly lower risk. As noted, this cautious asset allocation may link to risk preferences but also to portfolio and other regulations. As regards international diversification, this is shown to have little effect on return short of the full global 
portfolio, which offers 30 basis points more than the rest. There are shown to be benefits in terms of risk reduction up to 40 per cent foreign assets, while on average the global portfolio has a higher risk than the less internationally diversified ones. This is consistent with the result ${ }^{14}$ quoted above. These summary results do not apply to all countries. The UK sector had a higher actual return than a 50-50 portfolio, reflecting high levels of equity investment, while the USA and Canada had comparable returns, given pension fund portfolios are typically close to this portfolio benchmark. Elsewhere, due to higher bond shares than 50 per cent, returns and risks have typically been lower. Looking at comparable portfolios in terms of instruments (50-50 bonds and equities), the differing returns available in domestic financial markets are apparent. In Switzerland such a portfolio would return only 2.4 per cent, while in Sweden it would offer 8 per cent. Global portfolios minimise these extremes. Benefits of international investment are low in Germany, reflecting the appreciation of the currency, but are correspondingly high in the UK.

As regards the EMEs, the global portfolio would return much more than actual returns in Singapore and Malaysia over the 1970-1995 period, at a cost of higher risk. In Chile, data for returns are only available from 1980, reflecting the date of introduction of the personal pension system. Returns there were higher than the global portfolio over the same period, and risks lower. This period, however, may have been exceptional and indeed over 1996-1999, average returns of Chilean funds were only 5.8 per cent. ${ }^{32}$

Table 10 uses the data from Table 9 to offer a comparison of the returns and risks for internationally diversified portfolios relative to actual portfolios and the 50-50 domestic benchmark. The 'cleaner' comparison is the latter, reflecting as it does the location of the assets and not differences in portfolios in terms of instruments also. That said, it is clear than on average, OECD sectors could gain a markedly higher return by holding a 50-50 portfolio, and the cost in terms of risk is lowest for the 40 per cent foreign portfolio. For all the portfolios based on a 50-50 bond-equity split, the internationally diversified portfolios on average dominate the purely domestic one, with lower risk in all cases and (for the global portfolio) higher return. The corollary is that the same risk could have generated a higher return (via a higher share of equities).

Table 11 gives a third approach to the mean variance paradigm, by showing the Sharpe ratios on the differing portfolios. The measure is defined as the real return as a proportion of the standard deviation. It shows the reward to total volatility trade-off; mean variance preferences lead to a desire to maximise this measure. ${ }^{12}$ The actual portfolios have higher Sharpe ratios than those based on $50-50$ bonds and equities. This is not solely the consequence of more conservative allocations, since it is also true for the more aggressive UK pension funds, as well as those in Chile - but is not for Australia and Sweden. It may reflect wider diversification into assets such as real estate, liquidity and loans. There is still a benefit from international investment, with Sharpe ratios being markedly lower for the domestic 50-50 portfolio. In Australia, Sweden and the USA, the global portfolio has a higher Shape ratio than the actual portfolio, but in Canada, Japan and Switzerland it is virtually the same. For Chile and Singapore, Sharpe ratios are higher in actual than global portfolios, while this is not the case for Malaysia. 
Table 10: Mean variance 2: Comparing pension fund real returns and risks with foreign asset benchmarks (1970-95)

\begin{tabular}{|c|c|c|c|c|c|c|c|}
\hline & $\begin{array}{l}\text { Actual } \\
50-50\end{array}$ & $\begin{array}{l}\text { k/return less: } \\
20 \% \\
\text { foreign }\end{array}$ & $\begin{array}{l}40 \% \\
\text { foreign }\end{array}$ & $\begin{array}{l}\text { Global } \\
\text { portfolio }\end{array}$ & $\begin{array}{l}\text { Domestic } \\
20 \% \\
\text { foreign }\end{array}$ & $\begin{array}{l}40-50 \text { less: } \\
40 \% \\
\text { foreign }\end{array}$ & $\begin{array}{l}\text { Global } \\
\text { portfolio }\end{array}$ \\
\hline \multirow[t]{2}{*}{ Australia } & -1.7 & -2.2 & -2.8 & -4.3 & -0.5 & -1.0 & -2.6 \\
\hline & -6.1 & -5.1 & -4.7 & -6.8 & 1.0 & 1.4 & -0.7 \\
\hline \multirow[t]{2}{*}{ Canada } & 0.8 & 0.2 & -0.5 & -2.3 & -0.6 & -1.2 & -3.1 \\
\hline & -2.1 & -1.7 & -1.8 & -4.7 & 0.4 & 0.3 & -2.6 \\
\hline \multirow[t]{2}{*}{ Denmark } & -1.2 & -0.7 & -0.2 & 1.2 & 0.5 & 1.0 & 2.4 \\
\hline & -8.0 & -6.6 & -5.7 & -7.5 & 1.5 & 2.3 & 0.5 \\
\hline \multirow[t]{2}{*}{ Germany } & -0.4 & 0.1 & 0.6 & 2.1 & 0.5 & 1.0 & 2.5 \\
\hline & -11.8 & -10.2 & -9.4 & -12.5 & 1.6 & 2.4 & -0.7 \\
\hline \multirow[t]{2}{*}{ Japan } & -1.6 & -1.8 & -2.0 & -2.5 & -0.2 & -0.3 & -0.9 \\
\hline & -6.7 & -5.2 & -4.4 & -5.7 & 1.4 & 2.3 & 0.9 \\
\hline \multirow[t]{2}{*}{ Netherlands } & -0.9 & -0.8 & -0.6 & -0.2 & 0.2 & 0.3 & 0.8 \\
\hline & -12.3 & -11.2 & -10.2 & -8.7 & 1.1 & 2.1 & 3.6 \\
\hline \multirow[t]{2}{*}{ Sweden } & -5.8 & -5.5 & -5.2 & -4.2 & 0.3 & 0.7 & 1.6 \\
\hline & -6.9 & -4.5 & -2.6 & -1.6 & 2.4 & 4.3 & 5.3 \\
\hline \multirow[t]{2}{*}{ Switzerland } & -0.6 & -0.8 & -1.1 & -1.9 & -0.3 & -0.5 & -1.3 \\
\hline & -10.4 & -9.2 & -8.5 & -9.3 & 1.2 & 1.9 & 1.1 \\
\hline \multirow[t]{2}{*}{ UK } & 1.2 & 1.0 & 0.7 & 0.0 & -0.2 & -0.5 & -1.2 \\
\hline & -2.6 & -2.0 & -1.6 & -2.1 & 0.6 & 1.0 & 0.5 \\
\hline \multirow[t]{2}{*}{ USA } & 0.1 & -0.5 & -1.1 & -3.0 & -0.6 & -1.3 & -3.1 \\
\hline & -1.5 & -1.0 & -1.0 & -3.5 & 0.5 & 0.5 & -1.9 \\
\hline OECD & -1.9 & -1.8 & -1.9 & -2.2 & 0.0 & 0.0 & -0.3 \\
\hline Average & -6.1 & -5.1 & -4.5 & -5.7 & 1.0 & 1.6 & 0.4 \\
\hline Chile & & & & 3.9 & & & \\
\hline (1980-95) & & & & -9.5 & & & \\
\hline Singapore & & & & -3.7 & & & \\
\hline & & & & -13.2 & & & \\
\hline Malaysia & & & & -3.8 & & & \\
\hline & & & & -13.0 & & & \\
\hline
\end{tabular}

Source: Davis and Steil ${ }^{30}$, own calculations.

Table 11: Mean variance 3: Sharpe ratios (real return/standard deviation) (1970-95)

\begin{tabular}{|c|c|c|c|c|c|}
\hline & $\begin{array}{l}\text { Actual } \\
\text { portfolios }\end{array}$ & $50-50$ & $20 \%$ foreign & $40 \%$ foreign & $\begin{array}{l}\text { Global } \\
\text { portfolio }\end{array}$ \\
\hline Australia & 0.16 & 0.20 & 0.24 & 0.28 & 0.33 \\
\hline Canada & 0.48 & 0.33 & 0.40 & 0.45 & 0.48 \\
\hline Denmark & 0.44 & 0.32 & 0.32 & 0.31 & 0.20 \\
\hline Germany & 1.01 & 0.36 & 0.36 & 0.35 & 0.21 \\
\hline Japan & 0.43 & 0.36 & 0.40 & 0.44 & 0.43 \\
\hline Netherlands & 0.78 & 0.30 & 0.31 & 0.32 & 0.33 \\
\hline Sweden & 0.16 & 0.40 & 0.43 & 0.46 & 0.43 \\
\hline Switzerland & 0.23 & 0.13 & 0.15 & 0.18 & 0.22 \\
\hline UK & 0.46 & 0.30 & 0.33 & 0.36 & 0.39 \\
\hline USA & 0.38 & 0.33 & 0.39 & 0.44 & 0.49 \\
\hline OECD average & 0.45 & 0.30 & 0.34 & 0.36 & 0.35 \\
\hline Chile (1980-95) & 1.37 & & & & 0.5 \\
\hline Singapore & 0.78 & & & & 0.39 \\
\hline Malaysia & 0.23 & & & & 0.27 \\
\hline
\end{tabular}

Source: Own calculations. 
Table 12: Shortfall risk: Comparing pension fund minimum real returns with those on diversified and global portfolios (1970-95)

\begin{tabular}{llllll}
\hline & $\begin{array}{l}\text { Actual } \\
\text { portfolios }\end{array}$ & $\mathbf{5 0 - 5 0}$ & $\mathbf{2 0 \%}$ foreign & $\mathbf{4 0 \%}$ foreign & $\begin{array}{l}\text { Global } \\
\text { portfolio }\end{array}$ \\
\hline Australia & -33 & -42 & -40 & -38 & -31 \\
Canada & -17 & -21 & -22 & -23 & -26 \\
Denmark & -15 & -29 & -29 & -28 & -33 \\
Germany & -9 & -20 & -19 & -23 & -34 \\
Japan & -22 & -31 & -34 & -37 & -45 \\
Netherlands & -10 & -27 & -26 & -25 & -29 \\
Sweden & -36 & -25 & -22 & -20 & -23 \\
Switzerland & -11 & -28 & -29 & -30 & -31 \\
UK & -36 & -46 & -42 & -38 & -26 \\
USA & -21 & -22 & -23 & -24 & -26 \\
OECD average & -21 & -29 & -29 & -29 & -30 \\
Chile (1980-95) & -3 & & & & -22 \\
Singapore & -11 & & & & -34 \\
Malaysia & -16 & & & & -43 \\
\hline
\end{tabular}

Source: Own calculations.

Table 12 gives an indication of the shortfall risks to which sectors would be exposed in adopting the different investment approaches. This is shown simply by the lowest real return achieved during the period 1970-1995. (In most cases this was in 1973-1974, when the oil crisis led to high inflation and collapses in securities prices.) Actual portfolios tended to be better protected against such contingencies than the dummy 50-50 ones. Average worst-cases within the sample are -21 per cent for the actual portfolios as opposed to -30 per cent for the benchmark ones. Similar results obtain for the EMEs. Of course, hedging could reduce the potential costs from such market falls. In Australia, Sweden and the UK, the worst case for the actual portfolio is more adverse than for the constructed global portfolio. Note also that in the Asian crisis, domestic stock markets in the affected countries fell by 50 per cent or more, while the exchange rates also fell 50 per cent (Table 13). Ceteris paribus, foreign assets would thus have risen in value, offsetting losses on domestic stocks.

It was noted that the correlation of domestic share prices with world indices tends to increase in bear markets, reducing the seeming diversification benefits of international investment. This pattern reflects common behaviour of institutional investors (often repatriating their holdings) as well as common fundamentals across the world. Table $14,{ }^{33}$ illustrates these patterns in the bear markets of 1972 and 2001. For example, in 1972 the average correlation of monthly share price changes with those in the world market was 0.53 while in 1975 it was 0.69 . This is not precisely mirrored in the country data, but a general tendency is apparent (the US correlation is high because it represents a large share of the world market). Meanwhile in the recent period, when global financial integration had in any case ensured a much higher level of correlations, the highest correlation is again apparent late in the bear market in 2001 and 2002, with all countries except Japan having correlations of 0.88 or more. These are much higher than the average correlations shown in Table 1 .

Table 15 shows a comparison of pension fund returns with average earnings growth, relevant for ALM. The figures in the table show the 
Table 13: Asset price changes in Asian markets, 1 July 1997 to 18 February 1998 (per cent)

\begin{tabular}{llc}
\hline & Equity market & US\$ exchange rate \\
\hline Indonesia & -81.2 & -73.5 \\
S Korea & -32.3 & -48.1 \\
Thailand & -47.9 & -43.2 \\
Malaysia & -59.0 & -33.2 \\
Singapore & -45.0 & -13.2 \\
Hong Kong & -36.6 & 0 \\
\hline
\end{tabular}

Table 14: Correlation of share prices with world indices in bear markets

\begin{tabular}{lllllllll}
\hline & UK & USA & Germany & Japan & Canada & France & Italy & $\begin{array}{l}\text { Country } \\
\text { averages }\end{array}$ \\
\hline 1972 & 0.74 & 0.83 & 0.47 & 0.63 & 0.66 & 0.17 & 0.22 & 0.53 \\
1973 & 0.64 & 0.96 & 0.51 & 0.65 & 0.88 & 0.45 & 0.03 & 0.59 \\
1974 & 0.59 & 0.95 & 0.39 & 0.09 & 0.78 & 0.80 & 0.50 & 0.59 \\
1975 & 0.72 & 0.96 & 0.51 & 0.72 & 0.72 & 0.50 & 0.69 & 0.69 \\
1998 & 0.92 & 0.94 & 0.87 & 0.75 & 0.93 & 0.81 & 0.72 & 0.85 \\
1999 & 0.71 & 0.97 & 0.88 & 0.61 & 0.85 & 0.86 & 0.54 & 0.77 \\
2000 & 0.78 & 0.96 & 0.44 & 0.54 & 0.81 & 0.66 & 0.22 & 0.63 \\
2001 & 0.96 & 0.98 & 0.95 & 0.72 & 0.89 & 0.95 & 0.90 & 0.91 \\
2002 & 0.98 & 0.99 & 0.95 & 0.40 & 0.88 & 0.97 & 0.95 & 0.88 \\
\hline
\end{tabular}

Source: $\mathrm{MSCl}$

headroom over average earnings available from the different investment portfolios. On average, the headroom is much greater for the $50-50$ portfolios than for the actual returns obtained. Indeed, in Australia, Sweden and Switzerland, the returns are less than 1 per cent above average earnings, a quantity which is easily absorbed by transactions costs. Comparing the portfolios with different levels of international investment, headroom is higher for the global portfolio. In the EMEs, actual returns fall far short of average earnings in Singapore and Malaysia - international investment in a global portfolio would have improved the situation considerably. This is not the case in Chile, however.

Table 16 shows the correlations between the real asset returns and average earnings and inflation. It is desirable to have a zero correlation with inflation (so inflation does not affect real asset returns), and a strong positive correlation with average earnings (to ensure asset growth is in line with liabilities). In fact, portfolios are negatively correlated with both. For inflation, this means that high inflation leads to a low return on assets. It is notable, however, that the global portfolio suffers least from this problem, and the actual portfolios are much more vulnerable. As regards earnings, the correlation is close to zero, and is highest for the actual portfolio. Interestingly, the domestic 50-50 portfolio is less negatively correlated with earnings than is the global portfolio.

We suggest that results presented in this section are consistent with a nuanced view of the benefits of international investment. We find indeed that there are higher risk adjusted returns when portfolios are diversified internationally. On the other hand, shortfall risks are comparable and although the headroom over average earnings is higher for an internationally diversified portfolio, it is 
Table 15: Asset-Liability Management 1: Comparing pension fund real returns and global portfolio with real average earnings (1970-95)

\begin{tabular}{|c|c|c|c|c|c|c|}
\hline & $\begin{array}{l}\text { Real average } \\
\text { earnings }\end{array}$ & $\begin{array}{l}\text { Actual } \\
\text { portfolios }\end{array}$ & $50-50$ & $20 \%$ foreign & $40 \%$ foreign & $\begin{array}{l}\text { Global } \\
\text { portfolio }\end{array}$ \\
\hline \multirow[t]{2}{*}{ Australia } & 1.0 & 0.8 & 2.5 & 3.0 & 3.5 & 5.1 \\
\hline & 3.4 & 8.0 & 14.1 & 13.1 & 12.7 & 14.8 \\
\hline \multirow[t]{2}{*}{ Canada } & 1.3 & 3.5 & 2.7 & 3.3 & 3.9 & 5.8 \\
\hline & 2.4 & 7.6 & 9.7 & 9.3 & 9.4 & 12.3 \\
\hline \multirow[t]{2}{*}{ Denmark } & 2.4 & 2.5 & 3.6 & 3.2 & 2.7 & 1.2 \\
\hline & 3.5 & 7.5 & 15.6 & 14.1 & 13.3 & 15.1 \\
\hline \multirow[t]{2}{*}{ Germany } & 2.7 & 3.3 & 3.7 & 3.2 & 2.7 & 1.2 \\
\hline & 2.7 & 3.2 & 15.0 & 13.4 & 12.6 & 15.7 \\
\hline \multirow[t]{2}{*}{ Japan } & 2.4 & 2.1 & 3.7 & 3.9 & 4.0 & 4.5 \\
\hline & 3.0 & 7.2 & 13.9 & 12.5 & 11.6 & 13.0 \\
\hline \multirow[t]{2}{*}{ Netherlands } & 1.4 & 3.2 & 4.2 & 4.0 & 3.9 & 3.4 \\
\hline & 2.6 & 3.4 & 15.7 & 14.6 & 13.6 & 12.1 \\
\hline \multirow[t]{2}{*}{ Sweden } & 1.4 & 0.8 & 6.6 & 6.3 & 5.9 & 5.0 \\
\hline & 3.5 & 9.7 & 16.6 & 14.2 & 12.3 & 11.3 \\
\hline \multirow[t]{2}{*}{ Switzerland } & 1.5 & 0.2 & 0.8 & 1.1 & 1.3 & 2.1 \\
\hline & 2.1 & 5.6 & 16.0 & 14.8 & 14.1 & 14.9 \\
\hline \multirow[t]{2}{*}{ UK } & 2.8 & 3.0 & 1.8 & 2.1 & 2.3 & 3.1 \\
\hline & 2.3 & 10.5 & 13.1 & 12.5 & 12.1 & 12.6 \\
\hline \multirow[t]{2}{*}{ USA } & -0.2 & 4.8 & 4.6 & 5.3 & 5.9 & 7.8 \\
\hline & 1.9 & 9.9 & 11.4 & 10.9 & 10.9 & 13.4 \\
\hline OECD & 1.7 & 2.7 & 4.6 & 4.5 & 4.6 & 4.9 \\
\hline Average & 2.7 & 6.9 & 13.0 & 12.0 & 11.4 & 12.6 \\
\hline Chile & 3.2 & 9.8 & & & & 5.9 \\
\hline \multirow{3}{*}{$\begin{array}{l}\text { (1980-95) } \\
\text { Singapore }\end{array}$} & 5.7 & 3.8 & & & & 13.4 \\
\hline & 6.9 & -5.6 & & & & -1.8 \\
\hline & 3.3 & 2.1 & & & & 15.1 \\
\hline \multirow[t]{2}{*}{ Malaysia } & 4.4 & -1.4 & & & & 2.3 \\
\hline & 2.9 & 1.0 & & & & 14.3 \\
\hline
\end{tabular}

Source: Davis and Steil ${ }^{30}$, own calculations.

not the case that the correlation with average earnings is more favourable.

\section{Policy issues}

This final section assesses some of the policy issues arising from international investment of pension funds. The focus is on two aspects: whether regulations should be set to limit international investment and; whether international investment can help protect against future capital market turbulence as the population ages in OECD countries.

\section{Portfolio regulations bearing on international investment}

Two main issues arise when deciding if limits on international investment are appropriate. ${ }^{34}$ First, there is the question whether such limits reduce risks, taking a broad view of the investment needs of pension funds. Secondly, there is the issue whether, abstracting from risk, there is a benefit to restricting international investment to stabilise the macroeconomy or develop the capital market. The general case against portfolio regulations on international investment are parallel to those against restrictions on portfolios more generally. As summarised by European Commission, ${ }^{35}$ they are 'in the way of optimisation of the asset allocation and security selection process, and therefore may have led to sub-optimal return and risk taking'. Focusing on pension funds, foreign asset restrictions have a number of adverse consequences: 
Table 16: Asset-Liability Management 2: Correlations of returns with inflation and average earnings

\begin{tabular}{|c|c|c|c|c|c|c|}
\hline & & $\begin{array}{l}\text { Actual } \\
\text { portfolios }\end{array}$ & $50-50$ & $20 \%$ foreign & $40 \%$ foreign & $\begin{array}{l}\text { Global } \\
\text { portfolio }\end{array}$ \\
\hline \multirow[t]{2}{*}{ Australia } & Inflation & -0.49 & -0.44 & -0.41 & -0.37 & -0.17 \\
\hline & Earnings & -0.45 & -0.40 & -0.43 & -0.46 & -0.45 \\
\hline \multirow[t]{2}{*}{ Canada } & Inflation & -0.42 & -0.39 & -0.40 & -0.38 & -0.38 \\
\hline & Earnings & -0.24 & -0.27 & -0.24 & -0.19 & -0.06 \\
\hline \multirow[t]{2}{*}{ Denmark } & Inflation & -0.29 & -0.11 & -0.13 & -0.14 & -0.14 \\
\hline & Earnings & -0.37 & -0.12 & -0.19 & -0.27 & -0.43 \\
\hline \multirow[t]{2}{*}{ Germany } & Inflation & -0.17 & -0.25 & -0.21 & -0.15 & -0.15 \\
\hline & Earnings & -0.16 & -0.38 & -0.45 & -0.51 & -0.51 \\
\hline \multirow[t]{2}{*}{ Japan } & Inflation & -0.62 & -0.50 & -0.54 & -0.58 & -0.58 \\
\hline & Earnings & 0.04 & 0.05 & 0.04 & 0.02 & -0.03 \\
\hline \multirow[t]{2}{*}{ Netherlands } & Inflation & -0.53 & -0.40 & -0.40 & -0.40 & -0.40 \\
\hline & Earnings & 0.04 & -0.07 & -0.11 & -0.16 & -0.32 \\
\hline \multirow[t]{2}{*}{ Sweden } & Inflation & -0.33 & 0.02 & -0.01 & -0.06 & -0.06 \\
\hline & Earnings & -0.03 & -0.17 & -0.16 & -0.15 & -0.06 \\
\hline \multirow[t]{2}{*}{ Switzerland } & Inflation & -0.40 & -0.29 & -0.31 & -0.32 & -0.32 \\
\hline & Earnings & -0.10 & -0.24 & -0.25 & -0.25 & -0.20 \\
\hline \multirow[t]{2}{*}{ UK } & Inflation & -0.49 & -0.42 & -0.44 & -0.45 & -0.45 \\
\hline & Earnings & 0.14 & 0.07 & 0.09 & 0.10 & 0.14 \\
\hline \multirow[t]{2}{*}{ USA } & Inflation & -0.66 & -0.64 & -0.66 & -0.65 & -0.65 \\
\hline & Earnings & 0.29 & 0.27 & 0.29 & 0.30 & 0.27 \\
\hline OECD & Inflation & -0.41 & -0.33 & -0.34 & -0.34 & -0.32 \\
\hline Average & Earnings & -0.12 & -0.15 & -0.17 & -0.18 & -0.19 \\
\hline Chile & Inflation & 0.11 & & & & 0.16 \\
\hline Singapore & Inflation & -0.97 & & & & -0.20 \\
\hline Malaysia & Inflation & -0.96 & & & & -0.55 \\
\hline
\end{tabular}

Source: Own calculations.

In terms of risk and return optimisation, they are likely to enforce holdings of a portfolio below the efficient frontier, because they typically insist on high proportions of bonds and domestic assets. They focus unduly on the risk and liquidity of individual assets and fail to take into account the fact that, at the level of the portfolio, default risk and price volatility can be reduced by diversification. They hence increase risk for a given return by reducing the extent to which the diversification benefits of international investment may be attained. For pension funds, the degree to which such regulations actually contribute to benefit security is open to doubt. This relates to the link of liabilities to average earnings growth (as well as the vulnerability of liabilities to regulatory changes) ${ }^{36}$ besides the fact that appropriate global diversification of assets can eliminate idiosyncratic risk.
For DC funds, it is hard to argue a sound case for such rules, given the superior alternative of prudent person rules. They can even be said to expose beneficiaries to currency risk, given that beneficiaries will want to spend some of their income on foreign goods and services, and the domestic currency may depreciate. There seems little evidence that DC investors need 'protecting from themselves' ie prevent from taking high risks by quantitative restrictions. Indeed, in practice, experience suggests that US investors in individual DC funds at least historically tended to be too cautious to develop adequate funds at retirement, while companies running DC funds may invest excessively cautiously to avoid lawsuits. A case could be made (as in Chile ${ }^{37}$ ) that a danger with unrestricted investments would be that firms providing pension contracts would seek to boost yield to attract clients, at a cost 
of excessive risk which could ultimately be borne by the government. But these tendencies could also be dealt with by a prudent person rule.

Portfolio limits would also appear to be inappropriate for $\mathrm{DB}$ pensions, given the 'buffer' of the company guarantee for the beneficiaries and risk sharing between older and younger workers, and if benefits must be indexed. Clearly, in such cases, portfolio regulations may affect the cost to companies of providing pensions, if it constrains managers in their choice of risk and return, forcing them to hold low yielding assets, and possibly increasing their risks and costs by limiting their possibilities of diversification. Indeed, restrictions on foreign assets may prevent appropriate account being taken of the duration of the liabilities (which may differ sharply between funds, as well as over time), and related changes in risk aversion. They also render difficult or impossible the application of appropriate ALM techniques for maturity matching, because such techniques may require sharp variations in the portfolio between domestic and foreign equities to bonds, and use of derivatives. If portfolio regulations limit use of derivatives, abstracting from other operative limits, they will force the institution either to hold low-yielding assets or expose itself to unnecessary risks, notably in international markets.

For all systems, restrictions encourage national governments to treat pension funds as means to finance budgetary requirements (by enforcing high portfolio shares of government debt), in a way that could not occur under a prudent person rule where international diversification is permitted. Holdings of government debt are vulnerable to monetisation as government creates inflation to reduce its debt burden. Taking a broader view, in the case of restrictions which explicitly or implicitly ${ }^{38}$ oblige pension funds to invest in government bonds, which must themselves be repaid from taxation, there may be no benefit to capital formation and the 'funded' plans may at a macroeconomic level be virtually equivalent to pay-as-you-go.

As previously noted, international investment will forestall the point at which pension fund investment becomes so large as to face diminishing returns domestically, so restrictions bring this point closer. Also there may be a benefit at a national level if national income is subject to frequent terms-of-trade shocks owing to the position of being largely dependent on commodities for export earnings, while export earnings account for a large proportion of GDP, as is common in developing countries. Hence, holdings of assets offshore can actually help to contribute to greater stability of national income. ${ }^{39}$

Some additional points apply. For example, asset restrictions such as those on foreign assets are inflexible and typically cannot be changed rapidly in response to changing conjunctural economic circumstances and movements in domestic or international securities, currency and real estate markets; they also may find it difficult to adapt to structural changes in financial asset markets, such as EMU. If enforced strictly, they may give incentives to asset managers to hold proportions of risky assets which fall well short of the limits, to avoid breaching them when markets perform well and prices rise. This compounds the loss of potential risk reduction for a given return. They may limit tactical asset allocation - there is no incentive for the institutional investor to nominate investment managers with skills to achieve higher return and lower risk, by equity and international investment. Competition among asset 
managers is discouraged if their main function is to meet quantitative asset restrictions.

As was noted previously, the case for international diversification applies particularly strongly to emerging market economies. Nevertheless, some possible exceptions are often suggested to the argument for liberalisation, which also apply notably in emerging market economies.

Some issues arise in the context of capital outflow controls in developing countries. Exchange controls have in the past been - justifiably — imposed during foreign exchange crises to deal with capital flight, to avoid a sharp and costly overshooting of the currency, but often kept in looser form once normal conditions were re-established. ${ }^{39}$ It would be feasible ${ }^{40}$ to gain the diversification benefits of international investment without risk of capital flight by use of appropriate swap contracts. Foreign asset restriction can ease the fiscal cost of moving from a pay-as-you-go to a funded scheme. For example in Chile, pension fund development facilitated internal resource transfers, enabling the Chilean government to service its international debts without extreme fiscal adjustment which was damaging elsewhere to the real economy, by providing a domestic source of borrowing without requiring excessively high interest rates (in fact, the debt was generally CPI-indexed).$^{39}$ Later, the demand of pension funds enabled debt conversion - by both private and public institutions - to occur smoothly. $\mathrm{He}$ argues that the process would have been less smooth if international investment had been permitted.

Some would also argue that restrictions are needed to boost development of domestic capital markets and hence growth. Most Latin American countries with recent pension reforms restrict international investment. This is a complex, threefold issue: Do capital markets contribute to economic growth? Do pensions contribute to capital markets? And is this the case only if foreign investment is restricted? The evidence on the first point is fairly clear, both for capital markets and banks. ${ }^{41}$ There is some support for the link to pension funds to capital market development; most is based on Chilean experience, ${ }^{42}$ although some work also suggests benefits for a range of EMEs ${ }^{43}$ as pension funds are seen to increase the supply of long-term finance, financial innovation, infrastructure modernisation and possibly increase household saving. On the other hand, besides requiring fixed costs of set-up, development of pension and insurance industries, or even domestic capital markets, may be contrary to the comparative advantage of EMEs. ${ }^{9}$

Even if pension funds can aid growth of capital markets, openness to foreign investment may also achieve this objective. Assuming sound and transparent economic policy, competition and financial regulation, this would itself be encouraged by allowing international investment by domestic institutions, because it would give foreign investors confidence that the repatriation of their portfolios will not itself be restricted in future. Meanwhile, home bias even in the absence of such restrictions would lead to ample inflows to domestic instruments. ${ }^{44}$

There could be a rationale for portfolio regulations (albeit not minima) if fund managers as well as regulators are highly inexperienced and the markets volatile and open to manipulation by insiders. In a sense, they ensure portfolio diversification in a rough and ready way, and avoid risk becoming excessive in such cases. A corollary is that restrictions may justifiably be eased as expertise 
develops, and such arguments do not support international investment restrictions. This point applies more generally where regulators have initial doubts about internal controls in institutions, as well as about the industry's capacity for self-regulation and related governance structures. Moreover, compliance with portfolio limits is more readily verified and monitored by supervisors than for prudent person rules. The latter requires a high degree of transparency of institutions, and strict supervisory controls on investor malpractice (such as occurred in the Maxwell case ${ }^{45}$ ) as well as on self-regulatory bodies. But even if this argument is accepted, rules should be eased or switched to prudent person once experience is gained. On balance, we consider the liberal approach to be best both for OECD countries and EMEs.

\section{Some longer term risks}

Before concluding, it is important to assess what will happen to asset returns when global ageing takes place in coming decades. ${ }^{46}$ Will international investment help? Various predictions can be made.

During the transition phase as the working population ages while accumulating for retirement, there will be considerable demand for securities, notably in the form of equities (where regulations permit) and bonds. This will be enhanced as more countries currently dependent on pay-as-you-go switch relatively to funding (as witness recent steps by Germany and Italy). Given the contrasting portfolios of institutional investors and households, and the evidence of a lack of offsetting shifts in portfolios when institutional investment increases ${ }^{47}$ relative demand for deposits is likely to decline. Over time, there will be a shift within demand for securities from equity to bond-related instruments because of the growing maturity of pension schemes, and the increased demand for annuities per se would necessitate holding of shorter duration assets.

Such flows arising from funding will not be purely domestic, to the extent that ageing occurs at different rates in different countries. Net flows will arise from balance of payments surpluses in countries which are ageing most rapidly, offset by deficits in slower ageing countries, ${ }^{48}$ although such flows could arise via banking flows or foreign direct investment (FDI) as well as pension portfolio flows. Reflecting desire for diversification, and subject to portfolio regulations, it seems likely that there will be much greater gross capital flows between OECD countries and from OECD to EME countries during this phase, in the form of bond and equity finance. These are likely to exceed considerably the amplitude of net flows (ie arising from saving-investment imbalances and consequent balance of payments disequilibria). ${ }^{49}$

Experience suggests that a large share of OECD pension saving directed to EMEs can lead to bubbles and financial stability risks in the latter owing to institutional behaviour. This supports the need for pension funds in EMEs to invest globally rather than solely concentrating on the home market. Owing, for example, to autonomous shocks affecting profitability and creditworthiness, there may be periodic flights of investable funds back to the OECD or to other EMEs. Securities are in principle much easier to repatriate than bank loans. Indeed, behaviour of OECD institutional investors is already widely considered to destabilise EMEs, not least owing to their tendency to 
invest in EMEs as a bloc rather than focusing closely on individual countries' fundamentals. ${ }^{50}$

Looking further ahead, when an increasing proportion of the population retires in the rapidly ageing OECD countries and begins to live on the accumulated assets, domestic demand for securities in OECD countries could fall sharply, which could entail withdrawal of financing from EMEs. Decumulation is an ineluctable process for DB pension funds, ${ }^{51}$ and suggest that they will cease to contribute to US net saving around 2024. They note, however, that this effect is unlikely to occur for DC funds in the foreseeable future. Given the need to finance annuities, demand for equities would fall more than demand for bonds. ${ }^{52}$ Poterba ${ }^{53}$ focuses on extant information on age-specific asset holdings (excluding DB pension funds), corrected for cohort effects to evaluate this issue. He concludes that asset demands may indeed rise as households age, and notes that surveys suggest that there is a decline in risk tolerance at ages over 65 , but suggests that there is less evidence of a downturn in asset holdings at the end of the life cycle. He thus considers that a sharp fall in demand for securities is unlikely to arise in coming decades. ${ }^{54}$

Econometric evidence ${ }^{46}$ shows that demographics have had a significant impact on US, panel and aggregated OECD stock prices and bond yields from 1950-1999, even in the presence of standard additional independent variables. The results show that the size of the 40-64 age cohort has a strong important positive influence on asset prices, a support that would be removed as its share of the population declines, while more tentatively the $65+$ cohort has a negative effect. Projections suggest that the equity price is set to come under downward pressure, other things equal, from 2015 onwards, while the real interest rate could rise to historic peaks only previously seen in the early 1980s. These tentative results suggest a severe downturn is possible, thus underlining the potential market risks associated with sole reliance on fully funded pension schemes.

There could nevertheless be offsetting factors. Even if there were to be net decumulation of securities by OECD investors, global demand will also depend on the degree to which rapidly developing countries, eg in the Far East or Latin America, experience slower demographic ageing and thus provide a countervailing factor in the context of globalised financial markets. Note, however, that maintaining global demand for securities would require them not only to substitute for capital inflows from OECD countries, but also to generate substantial surpluses to cover declines in demand for securities in OECD countries themselves. The more EMEs that fund pensions, and the more rapid their economic development, the more likely this is. The increase and subsequent decrease in savings flows will be balanced by rises and falls in equity issues, with little effect on prices and returns. ${ }^{55}$ Also the increase in the ratio of pensioners to workers is already underway, and will continue steadily rather than abruptly, again casting doubt on the idea of a cycle. Or at least, the market will take on board such gradual future shifts without major and abrupt adjustments in prices. Furthermore, OECD countries are ageing at different rates and there may be offsetting demands for securities from EMEs.

Despite these counter arguments to the 'baby bust', we suggest that there are grounds for caution as a consequence of these projected patterns, which international investment alone cannot resolve, as it is a systematic risk to the global portfolio. They clearly justify a retention of some element of 
pay-as-you-go as a form of insurance against a future crisis in global capital markets. It is evident that international investment will still be beneficial in reducing the risks from ageing as compared to purely domestic investment, given that countries will age at different rates in the coming decades. And indeed, in many countries balance of payments surpluses due to ageing will make liberalisation of international investment essential. EMEs should develop domestic pension fund sectors also as a bulwark against eventual withdrawal of OECD funds.

\section{Conclusions}

Data confirm the theory that international investment allows superior investment performance in terms of risk and return. Pension funds are well placed to take advantage of the benefits of international investment - to an extent that depends on the maturity of the fund and the investment approach. There are sizeable differences in international investment by the pension fund sectors in the countries studied. Whereas some degree of home bias is likely to occur naturally, it is undesirable for regulations to enforce tighter limits on foreign assets than these market forces would suggest. The arguments favouring such restrictions are weak. The future of funding itself seems likely to be turbulent given the growing scope of asset flows and the future decumulation when ageing accelerates in OECD countries. These developments do not negate the case for international investment, but they do suggest a need to retain elements of a pay-as-you-go system, as a form of insurance.

\section{References}

1 An earlier version of this paper was presented at the Senior Level Policy Seminar, Caribbean Centre for Monetary Studies, Trinidad, 3rd May, 2002. The author thanks Mukul Asher and Dennison Noel for their assistance.

2 See Davis, E. P. and Steil, B. (2001) 'Institutional Investors', MIT Press, Cambridge, MA. This paper draws on this work throughout.

3 See Solnik, B. (1988) 'International Investments', Addison Wesley, Reading, MA, and Solnik, B. (1998) 'Global asset management', Journal of Portfolio Management, Summer 1998, pp. 43-51.

4 Baxter, M. and Jermann, U. J. (1997) 'The international diversification puzzle is worse than you think', American Economic Review, Vol. 87, pp. 170-180, go further and suggest that since human capital is non-diversifiable and labour income growth and domestic capital market returns are strongly correlated, it is optimal to sell short domestic securities and hold wealth in a portfolio of foreign assets.

5 This will be of particular importance to DB pension funds in which liabilities are tied to wages and hence rise as the profit share falls. Similarly, at an individual firm level, investment in competitors' shares hedges against a loss of profits due to partial loss of the domestic market.

6 As discussed, there remains an issue whether common ageing of OECD countries will render this diversification benefit ineffective.

7 Blake, D. (1997) 'Pension funds and capital markets', Discussion Paper No PI-9706, The Pensions Institute, Birkbeck College, London.

8 Technically, these results imply inefficiency and/or slow adjustment of global capital markets.

9 Kotlikoff, L. J. (1998) 'The right approach to pension reform', Paper presented at the Asian Development Bank conference on Pension Reform, Manila, December 1998.

10 Reisen, H. (1997) 'Liberalizing foreign investments by pension funds: Positive and normative aspects' World Development, Vol. 25, No. 1, pp. 1173-82.

11 See, for example Meric, I. and Meric, G. (1989) 'Potential gains from international portfolio diversification and intertemporal stability and seasonally in international stock market relationships', Journal of Banking and Finance, Vol. 13, Nos. 4-5, pp. 627-40.

12 Drawn from Solnik, B. and De Freitas, A. (1988) 'International factors of stock price behaviour', in Khoury, S. and Ghosh, S. (eds) 'Recent Developments in International Finance and Banking', Lexington Books, Lexington. Cited in Bodie, Z., Kane, A. and Marcus, A. J. (1999) 'Investments', 4th ed, McGraw Hill, Boston, MA.

13 Jorion, P. and Goetzmann, W. N. (1999) 'Global stock markets in the twentieth century', Journal of Finance, Vol. 54, pp. 953-980.

14 Greenwood, J. G. (1993) 'Portfolio investment in Asian and Pacific economies: Trends and prospects', Asian Development Review, Vol. 11, No. 1, pp. 120-150.

15 Mitchell, O. S. (1997) 'Building an environment for pension reform in developing countries', in Bodie, Z. and Davis, E. P. (eds), 'Foundations of Pension 
Finance', Pension Research Council, The Wharton School, London.

16 For example, French, K. R. and Poterba, J. M. (1993) 'Investor diversification and international equity markets' in Thaler, R. H., (ed) 'Advances in Behavioral Finance', New York: Russell Sage Foundation, suggest that the low level of Japanese investment in the US Stock Exchange could be rationalised only by a five percentage points higher than expected annual yield in Japan compared with the USA.

17 Solnik, B., Boucrelle, C. and Le Fur, Y. (1996) 'International market correlation and volatility', Financial Analysts Journal, September/October, Vol. 52, No. 5, pp. 17-35.

18 Howell, M. and Cozzini, A. (1990) 'International Equity Flows', Salomon Bros, London.

19 See Eichholz, P. M. A. (1996) 'Does international diversification work better for real estate than for stocks and bonds?', Financial Analysts Journal, January-February, Vol. 52, No. 1, pp. 56-62.

20 See Kang, J. and Stulz, R. (1995) 'Why is there a home bias? An analysis of foreign portfolio equity ownership in Japan', NBER Working Paper No. 5166.

21 Frankel, J. A. and Schmukler. S. L. (1996) 'Country fund discounts and the Mexican crisis of December 1994: Did local residents turn pessimistic before international investors?', International Finance Discussion Papers 563, Board of Governors of the Federal Reserve System.

22 Blake, D. and Timmermann, A. (2002) 'Performance benchmarks for institutional investors: Measuring, monitoring and modifying investment behaviour' in Knight, J. and Satchell, S. (eds) 'Performance Measurement in Finance: Firms, Funds and Managers', Butterworth Heinemann, Oxford.

23 Estimates of this have been produced by Pinkowitz, L., Stulz, R. M. and Williamson, R. (2001) 'Corporate governance and the home bias', NBER Working Paper, No 8680.

24 See Goodman, R. (2000) 'The development of the prudent man concept in relation to pension funds', Journal of Pensions Management, Vol. 6, No. 3, pp. 219-224 and Davis, E. P. (2002) 'Prudent person rules or quantitative restrictions? The regulation of long-term institutional investors' portfolios', Journal of Pension Economics and Finance, Vol. 1, No. 1, pp. 157-191.

25 As an example, in the UK, the accounting rule FRS17 enforces mark to market, on balance sheet accounting for pension liabilities with no smoothing and use of a corporate bond yield discount rate. It is considered to be leading to widespread abandonment of DB funds altogether (Davis 2001b).

26 These regulations were abolished in Germany after the impact on life insurers' and pension funds' solvency of asset price falls following the terrorist attacks on the USA on 11th September, 2001 became apparent.

27 For further detail see Davis, E. P. (1998) 'Regulation of pension fund assets', in Blommestein, $\mathrm{H}$. and Funke, N. (eds) 'Institutional Investors in the New Financial Landscape', OECD, Paris.

28 A cross-check with the MSCI world equity index revealed similar risks and returns.

29 In the 1970s there was a hyperinflation, which contributed to the demise of the pay-as-you-go system.

30 It may be added that earlier data (in Davis and Steil 2001) shows that even for some of the sectors shown to have substantial assets, this is a relatively recent phenomenon. In 1970, the data suggest that only the Netherlands ( 7 per cent) and the UK (2 per cent) had substantial foreign assets at all, due in most cases to exchange controls as well as specific regulations on pension funds.

31 Bateman, H. and Piggott, J. (1993) 'Australia's mandated retirement income scheme: An economic perspective', Retirement Income Perspectives. Two papers prepared for the office of EPAC, July.

32 Palacios, R. and Pallares-Mirelles, M. (2000) 'International Patterns of Pension Provision', World Bank, Washington DC.

33 Davis, E. P. (2003) 'Comparing bear markets, 1973 and 2000', National Institute Economic Review, Vol. 183, pp. 78-89.

34 Davis, E. P. (1998) 'Policy and implementation issues in reforming pension systems', Working Paper No. 31, European Bank for Reconstruction and Development, London.

35 European Commission (1999) 'Rebuilding pensions, security, efficiency, affordability -

Recommendations for a code of best practice for second pillar pension funds', prepared by Pragma Consulting for DG-XV, European Commission, Brussels.

36 Indeed, in several countries, a false parallel seems to be drawn by regulators between life insurers and pension funds.

37 Davis, E. P. (1998) 'Investment of mandatory funded pension schemes', Discussion Paper No. PI-9908, The Pensions Institute, Birkbeck College, London and Gillion, C., Turner, J., Bailey, C. and Latulippe, D. (eds) (2000) 'Social Security Pensions: Development and Reform', International Labor Office, Geneva.

38 For example, by closing down all alternative investment strategies such as international diversification.

39 Fontaine, J. A. (1997) 'Are there good macroeconomic reasons for limiting external investments by pension funds? The Chilean experience', in Valdes-Prieto,, S. (ed) 'The Economics of Pensions', Cambridge University Press, Cambridge..

40 Bodie, Z. and Merton, R. (2001) 'International pension swaps', Discussion Paper No PI-0114, The Pensions Institute, Birkbeck College, London.

41 Davis, E. P. (2004) 'Financial development, institutional investors and economic performance', in Goodhart, C. (ed) 'Financial Development', Palgrave, London, UK. 
42 Holzmann, R. (1997) 'Pension reform, financial market development and economic growth, preliminary evidence from Chile', IMF Staff Papers, $44 / 2$.

43 Walker, E. and Lefort, F. (2001) 'Pension reform and capital markets: Are there any hard links?', World Bank Pension Reform Primer, December 2001.

44 Singapore, where pension assets are managed by public bodies, is an exception.

47 Davis, E. P. (2001) 'Regulation of private pensions - A case study of the United Kingdom', Occasional Paper No OPIS, Financial Services Authority, London.

46 Davis, E. P. (2002) 'Ageing and financial stability', in Auerbach, A. J. and Herrmann, H. (eds) 'Ageing, Financial Markets and Monetary Policy', Springer, Heidelberg and Davis, E. P. and Li, C. (2003) 'Demographics and financial asset prices in the major industrial economies', Brunel University Working Paper No 03-07.

47 King, M. A. and Dicks-Mireaux, L. (1988) 'Portfolio composition and pension wealth: An econometric study', in Bodie, Z., Shoven, J. B. and Wise, D. A., 'Pensions in the US Economy', University of Chicago Press, Chicago IL.

48 Boersch-Supan, A., Ludwig, A. and Winter, J. (2002) 'Ageing and international capital flows', in Auerbach, A. J. and Herrmann, H. (eds) 'Ageing, Financial Markets and Monetary Policy', Springer, Heidelberg.

49 Reisen, H. (1998) 'Warning; past pension fund performance is no guarantee for future performance', in Blommestein, H. and Funke, N. (eds) 'Institutional Investors in the New Financial
Landscape', OECD, Paris. This points to both the offsetting patterns of saving and the diversification benefits arising from EMEs as helpful in ensuring adequate returns on OECD pension funds that invest in EMEs, not least in the light of the tendency for returns in OECD countries to fall in coming decades. Blommestein, H. (1998) 'Ageing induced capital flows to emerging markets do not solve the OECD's basic pension problem', in Blommestein, H. and Funke, N. (eds) 'Institutional Investors in the New Financial Landscape', OECD, Paris On the other hand, points to the low returns and high risks of EMEs, in combination with increasing correlations with the OECD markets, which suggest that EME investment is not a panacea.

50 Buckberg, E. (1996) 'Institutional investors and asset pricing in emerging markets', Working Paper WP/96/2, International Monetary Fund.

51 Schieber, S. J. and Shoven, J. (1994) 'The consequences of population ageing on private pension fund saving and asset markets', NBER Working Paper No. 4665.

52 Brooks, R. (2000) 'Life cycle portfolio choices and asset market effects of the baby boom', IMF Working Paper WP/00/18.

53 Poterba, J. M. (1998) 'Population age structure and asset returns - an empirical investigation', NBER Working Paper No. 6774.

$54 \mathrm{He}$ admits however that his analysis fails to cover DB pension funds.

55 Neuberger, A. (1999). 'Long term savings flows and the capital market', Morgan Stanley Dean Witter Global Pensions Quarterly, January 1999. 